\title{
集合住宅における住戸の建築特性の影響構造 STRUCTURE OF INFLUENCE AMONG BUILDING DESIGN PARAMETERS OF DWELLING UNIT IN MULTI-UNIT RESIDENTIAL BUILDING
}

\author{
門 脇 耕 三*
}

\section{Kozo KADOWAKI}

\begin{abstract}
Building characteristics of dwelling unit in residential building, e.g. story height, floor area and lighting condition, effect on the choice range in designing other building characteristics e.g. ceiling height, room area and water-section positioning. The purpose of this paper is to describe the structure of influence among such building design parameters quantitatively.

Graphical modeling analysis was applied to multivariate data obtained from 158 existing dwelling units. It demonstrated a structure of influence using a "graph" defined in the graph theory. This graph is effective when assessing capacity of base building for interior design variety or for interior changes.
\end{abstract}

\section{Keywords : Open Building, S/I housing, Capacity, Dwelling unit design, Graphical modeling オープンビルディング，SI 住宅，キャパシティ，住戸計画，グラフィカルモデリング}

\section{1. 研究の背景と目的}

集合住宅において、良好な居住環境を長期に渡って維持していく ためには、インフィルと総称される内装や住戸設備などを、適切に 改修・更新していくことが、一つの有効な方法である。この時、経 年に伴って生じる様々な変化に対応するため、インフィルを物理 的・機能的に支える構造躯体や共用設備、寸なわちスケルトンは、 多様なインフィルを許容できるものであることが望ましい。

スケルトンにおいて実現可能なインフィルの多様さは、個々のス ケルトンの計画のされ方によって異なるが、この多様さの度合いを スケルトンのキャパシティと呼ぶ $\left.{ }^{1) 2}\right)_{0}$ キャパシティをスケルトンの 一種の性能として捉え、客観的に評価する手法を構築することは、 多様な住戸の実現、インフィル更新による住宅ストックの有効活用 といった課題に鑑みて、意義が大きい。一方で、キャパシティの評 価手法の構築は、以下に述べる理由により容易ではない。

そもそもキャパシティは、スケルトンによって規定される空間の 分割可能性や、分割された空間に対寸る用途や機能付加の自由度な ご、住戸配列や住戸計画の自由度に関する種々の性能概念を包含す る。個々の要素性能については、事務所建築における空間の分割可 能性と利用効率に関する岡村ら ${ }^{3}$ (4) 5)、階段室型集合住宅における諸 室の連結関係の組み替え可能性に関寸る安枝ら ${ }^{6}$ 、、集合住宅住戸に おける設備機器配置の自由度に関する $\mathrm{Li}^{7}{ }^{7}$ など、ある程度の研究の
積み重齐があるが、これらが複合された概念であるキャパシティを、 一義的に定義することは困難である。

一方で筆者ら ${ }^{8}$ は、既存の集合住宅住戸のキャパシティに関する 数量值型有識者アンケートを行い、その結果を統計的に分析するこ とによって、キャパシティの定量的評価手法を提案した。しかし、 ここでキャパシティ評価值の意味するところは明確ではないし、そ のためにキャパシティの質、すなわち、当該のスケルトンがどのよ うなインフィル計画に適したものであるかを判定する手法の構築に は至っていない。

ところでキャパシティとは、スケルトンがインフィル計画に与え る制約の負の効果であると考えることも出来る。筆者ら ${ }^{9}$ は、この 観点に基づき、住戸の階高、専有面積、採光条件などを変数として、 多数の既存集合住宅の住戸計画をパラメトリックに記述した上、変 数間の相関の強さを統計的に導いた。ここで、変数間の相関の強さ は、住戸のある建築的な特性が、他の特性に及ぼす影響力の強さを 表していると解釈できる。筆者ら ${ }^{9}$ は、ほとんどの変数が他の複数 の変数と影響関係をもつことを明らかにしたが、影響関係の強さを 単相関係数で表しているため、影響関係が認められた変数の対の中 に、他の変数の介在による圥長な影響関係で結ばれた対が存在する 可能性が高いことが課題であった。そこで本研究は、多変数間の直 接的な影響関係を明確にし、集合住宅の住戸計画において成立する
* 首都大学東京大学院都市環境学部建築学域 助教・修士 (工学)
Assistant Prof., Department of Architecture and Building Engineering, Graduate School of Urban Environmental Sciences, Tokyo Metropolitan University, M. Eng. 
建築特性の影響構造を明らかにすることを第一の目的とする。

また筆者ら ${ }^{9}$ は、このような考え方が、スケルトン / インフィル という、ビルディングシステムの単純な二元分割によらないキャパ シティの概念を示しうることを指摘している。つまり、与条件とな る変数の值によって定まる他の変数の值域は、住戸のある建築特性 が定まったときの、他の建築特性に関する計画可能域を示しており、 これは住戸の任意の部分によって定まるキャパシティに他ならない。 本研究は、以上のような考え方に基づいた、キャパシティの評価手 法を提示することを第二の目的とする。

\section{2. 研究の概要}

\section{1. 研究の対象}

研究の対象は、日本において 1980 年から 2004 年の間に建設され た、鉄筋コンクリート造および鉄骨鉄筋コンクリート造（コンクリ 一ト充填鋼管造を含む）の中層集合住宅の住戸であり、標本の大き さは 158 である。ここで中層集合住宅とは、建物高さ注 ${ }^{11}$ が $45 \mathrm{~m}$ 以 下のものと定義した。標本とした住戸は、すべて異なる住棟から抽 出したものであり、住棟の最上階、地上階、地階に位置する住戸、 および複層型の住戸は除外している。
分析に用いたデータは、標本とした住戸の新築時の図面より計測 した、19の量的変数からなる多変量データである。うち、18 変数は 住戸計画の特性を表す变数であり、1 変数は建設年である。建設年 を変数として加えたのは、住戸計画の特性を表す変数のうちいくつ

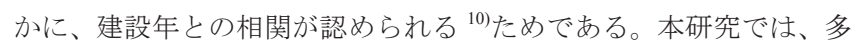
変量データに建設年を組み込んでおくことによって、後述する統計 的方法により、建設年を介した擬似相関を取り除く。なお、以上の データは筆者らの既往研究で得られたものの一部であり、標本の構

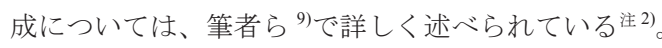

各変数の定義および統計量を、表 1 に示す。住戸の建築特性に関 する変数については、それぞれを便宜的に、住戸の断面計画に関す る変数、設備計画に関する变数、平面計画に関する変数の 3 種に分 類した。これらの変数は、全体として住戸計画の特徵をよく表すと 考えられる組合せであるが、住戸配列や、対象とした住戸以外の住 戸の特性を表寸変数は含まれていない。従って、本研究で报うキャ パシティは、住戸の領域が定まった上での、当該住戸の住戸計画に 関するキャパシティであると必然的に定義される。いうまでもなく、 住戸配列の自由度や、住戸の規模変更の自由度といった性能は、本 研究で扱うキャパシティの概念に含まれない。

表 1 分析に用いた変数の定義と統計量

\begin{tabular}{|c|c|c|c|c|c|c|c|}
\hline \multirow[b]{2}{*}{$\begin{array}{l}\text { 分 } \\
\text { 類 }\end{array}$} & \multirow[b]{2}{*}{$\begin{array}{l}\text { 番 } \\
\text { 号 }\end{array}$} & \multirow[b]{2}{*}{ 変数名 } & \multirow[b]{2}{*}{ 定義 } & \multirow[b]{2}{*}{ 単位 } & \multicolumn{3}{|c|}{ 統計量 } \\
\hline & & & & & $\begin{array}{l}\text { 最小值 } \\
\text { 最大値 }\end{array}$ & $\begin{array}{l}\text { 標本平均 } \\
\text { 標準偏差 }\end{array}$ & $\begin{array}{l}\text { 歪度 } \\
\text { 尖度 }\end{array}$ \\
\hline \multirow{4}{*}{$\begin{array}{l}\text { 断 } \\
\text { 面 } \\
\text { 計 } \\
\text { 画 }\end{array}$} & 1 & スケルトン天井高 & 当該住戸における階高より標準的なスラブ厚を減じた值。 & $\mathrm{mm}$ & $\begin{array}{l}2470.0 \\
3360.0\end{array}$ & $\begin{array}{r}2642.5 \\
153.9\end{array}$ & $\begin{array}{l}2.481 \\
7.852\end{array}$ \\
\hline & 2 & 標淮天井高 & 標準的な居室の天井高。 & $\mathrm{mm}$ & $\begin{array}{l}2300.0 \\
2700.0\end{array}$ & $\begin{array}{r}2460.3 \\
73.0 \\
\end{array}$ & $\begin{array}{l}1.180 \\
1.494\end{array}$ \\
\hline & 3 & スラブ段差 & \begin{tabular}{|l} 
スラブに段差が設けられている場合の段差寸法。 \\
逆梁の場合は、梁上端からスラブ上面までの寸法。
\end{tabular} & $\mathrm{mm}$ & $\begin{array}{r}0.0 \\
600.0\end{array}$ & $\begin{array}{l}104.2 \\
122.5\end{array}$ & $\begin{array}{l}1.568 \\
2.859\end{array}$ \\
\hline & 4 & スラブ下がり面積 & スラブに段差が設けられている場合の、スラブが下がった部分の面積。 & $\mathrm{m}^{2}$ & $\begin{array}{r}0.000 \\
110.885\end{array}$ & $\begin{array}{l}15.252 \\
24.743\end{array}$ & $\begin{array}{l}2.345 \\
4.985\end{array}$ \\
\hline \multirow{4}{*}{$\begin{array}{l}\text { 設 } \\
\text { 備 } \\
\text { 計 } \\
\text { 画 }\end{array}$} & 5 & 設備機器－排水竪管最大距離 & \begin{tabular}{|l} 
設備機器と、それに床下配管で接続する排水堅管との住戸平面上の最大直線距離。 \\
管が住戸専有部外に設けられている場合は、両者を結ぶ直線上の外周壁までの踓。
\end{tabular} & $\mathrm{m}$ & \begin{tabular}{r|r|}
0.000 \\
13.299
\end{tabular} & $\begin{array}{l}3.048 \\
1.669\end{array}$ & $\begin{array}{l}2.427 \\
9.863\end{array}$ \\
\hline & 6 & $\begin{array}{l}\text { 水趈り一採光可能外周壁 } \\
\text { 最短距離 }\end{array}$ & $\begin{array}{l}\text { 水趈り (キッチンを除く) から有効採光が得られる開口部を計画することが可能な壁面までの } \\
\text { 住戸平面上の最短のマンハッタン距離。 }\end{array}$ & $\mathrm{m}$ & $\begin{array}{l}0.000 \\
7.300\end{array}$ & $\begin{array}{l}2.216 \\
2.045\end{array}$ & $\begin{array}{r}0.303 \\
-1.056\end{array}$ \\
\hline & 7 & 排水堅管数 & 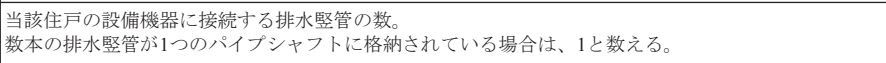 & （度数） & $\begin{array}{l}1 \\
4\end{array}$ & $\begin{array}{l}2.108 \\
0.719\end{array}$ & $\begin{array}{r}-0.059 \\
-0.810\end{array}$ \\
\hline & 8 & 住戸内排水竪管数 & $\begin{array}{l}\text { 住戸専有部に計画された排水堅管の数。 } \\
\text { 排水堅管数と同様、数本の排豎管が1つのパイプシャフトに格納されている場合は、1と数える。 }\end{array}$ & （度数） & $\begin{array}{l}0 \\
4\end{array}$ & $\begin{array}{l}1.551 \\
1.068\end{array}$ & $\begin{array}{r}-0.229 \\
-1.075\end{array}$ \\
\hline \multirow{9}{*}{$\begin{array}{l}\text { 平 } \\
\text { 面 } \\
\text { 計 } \\
\text { 画 }\end{array}$} & 9 & 専有面積 & $\begin{array}{l}\text { 当該住戸が区分所有されると仮定した場合の、住戸専有部分の面積。ただし、本研究では面積を壁心 } \\
\text { を基準として計測しているため、区分建物の専有面積とは一致しない。 } \\
\end{array}$ & $\mathrm{m}^{2}$ & \begin{tabular}{r|r}
31.540 \\
167.296
\end{tabular} & $\begin{array}{l}80.092 \\
19.945\end{array}$ & $\begin{array}{l}0.801 \\
1.670\end{array}$ \\
\hline & 10 & 有効採光壁面長 & 有効採光が得られる開口部を計画することが可能な壁面の水平断面長の合計。 & $\mathrm{m}$ & $\begin{array}{r}3.100 \\
49.090\end{array}$ & $\begin{array}{r}18.544 \\
9.473\end{array}$ & $\begin{array}{l}0.932 \\
0.279\end{array}$ \\
\hline & 11 & 私室面積 & \begin{tabular}{|l} 
私室面積の合計。 \\
私室からのみ到達可能な収納の面積は、私室面積に含める。
\end{tabular} & $\mathrm{m}^{2}$ & $\begin{array}{l}11.745 \\
77.495\end{array}$ & $\begin{array}{l}36.004 \\
10.600\end{array}$ & $\begin{array}{l}0.699 \\
1.648 \\
\end{array}$ \\
\hline & 12 & 公室面積 & \begin{tabular}{|l} 
公室（リビング・ダイニング・キッチンなど）の面積の合計。 \\
公室からのみ到達可能な収納の面積（納戸を除く）は、公室面積に含める。 \\
\end{tabular} & $\mathrm{m}^{2}$ & $\begin{array}{r}9.551 \\
51.395 \\
\end{array}$ & $\begin{array}{r}26.672 \\
8.124 \\
\end{array}$ & $\begin{array}{l}0.284 \\
0.186\end{array}$ \\
\hline & 13 & 水廻り面積 & 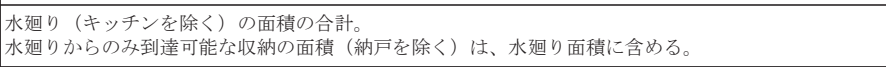 & $\mathrm{m}^{2}$ & $\begin{array}{r}4.964 \\
23.886\end{array}$ & $\begin{array}{l}8.795 \\
2.180\end{array}$ & $\begin{array}{r}3.113 \\
16.086 \\
\end{array}$ \\
\hline & 14 & 無空私室面積 & \begin{tabular}{|l} 
無空の私室の面積の合計。 \\
建築基準法第28条の4適用の続き間は無空の私室と見なす。 \\
\end{tabular} & $\mathrm{m}^{2}$ & $\begin{array}{r}0.000 \\
21.450\end{array}$ & $\begin{array}{l}1.665 \\
4.315 \\
\end{array}$ & $\begin{array}{l}2.468 \\
5.053\end{array}$ \\
\hline & 15 & 無空公室面積 & 無空の公室の面積をの合計。 & $\mathrm{m}^{2}$ & $\begin{array}{r}0.000 \\
26.000\end{array}$ & $\begin{array}{l}8.486 \\
6.583\end{array}$ & $\begin{array}{r}0.199 \\
-0.943\end{array}$ \\
\hline & 16 & 無空水廻り面積 & 無空の水廻り（キッチンを除く）の面積の合計。 & $\mathrm{m}^{2}$ & $\begin{array}{r}0.000 \\
23.886\end{array}$ & $\begin{array}{l}7.071 \\
3.176\end{array}$ & $\begin{array}{l}0.423 \\
4.506\end{array}$ \\
\hline & 17 & 私室数 & $\begin{array}{l}\text { 私室の数。有効採光を満たせないなどの理由で図面表記上は納戸などとされている場合でも、公室も } \\
\text { しくは郎下から直接出入り可能、かつ面積が } 6 \mathrm{~m}^{2} \text { 上小室は、私室として扱う。 }\end{array}$ & （度数） & $\begin{array}{l}1 \\
5\end{array}$ & $\begin{array}{l}2.949 \\
0.764\end{array}$ & $\begin{array}{r}-0.262 \\
0.965\end{array}$ \\
\hline & 18 & 建設年 & $\begin{array}{l}\text { 当該集合住宅が建設された西暦年。この変数のみ欠測値があり、その度数は7である。ただし、建設 } \\
\text { 年が不明な標本は全て、資料より確実に1980年以降に建設されたと判断したもである。 } \\
\end{array}$ & （西暦年） & $\begin{array}{l}1980 \\
2004\end{array}$ & $\begin{array}{r}1992.0 \\
5.8\end{array}$ & $\begin{array}{r}0.082 \\
-0.954\end{array}$ \\
\hline
\end{tabular}

* 本研究では、長さ、面積は全て図面上に表記された壁心を基準として計測している。

** 本研究では、公室、私室を、下記のように定義している。

公室 : 住戸の居室のうち、図面上で「居間」「食事室」「台所」もしくはそれに準ずる室名が表記され、当該住戸の居住者が共同で使用することが想定されている室であり、他の住戸居 住者の侵入を許さずに、1 人の居住者が専有した場合、他の居住者の日常的な生活に支障をきたすと考えられる室。

私室 : 住戸の居室のうち、上記で定義した公室以外の室。ただし、有効採光を満たせないなどの理由で、図面表記上は納戸などとされている場合でも、公室もしくは廊下から直接出入 り可能、かつ面積が $6 \mathrm{~m}^{2}$ 以上の室は、私室として报う。 


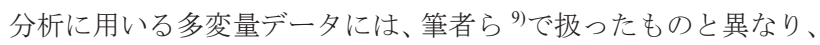
他の変数と何らかの関係式が成り立つ変数は含まれていない。例え ば筆者ら $\left.{ }^{9}\right)$ では、住戸の採光条件を表す指標として、有効採光の得 られる開口部を計画することが可能な外周壁の水平断面長の合計を、 住戸の専有面積で除した值を採用している。このようなデータ処理 は、外周壁の水平断面長と専有面積が正の相関を持つため、専有面 積の影響を除外することを目的としたものであるが、一方で、本研 究で扱う多変量データには、専有面積が変数として含まれているた め、単に上述したような外周壁の水平断面長の合計を、採光条件を 表す指標とした。このことは、本研究で適用する統計的方法が多変 量解析であり、全ての変数の線形独立性を担保する必要があるため である。しかし、本研究で適用する多変量解析法は、他の変数によ る影響を取り除いた分析を目的とするものであるため、そもそも筆 者ら 9)のようなデータ処理を必要としない。

\section{2. 分析の方法}

本研究では、以上のデータに対して、多変量解析法の一つである グラフィカルモデリングを適用する注3)。

グラフィカルモデリングは、変数間の因果構造を探索的にモデル 化するとともに、その妥当性を検証する統計的方法であり、変数間 の因果構造は、グラフを用いて表される。ここでグラフとは、ノー ド（点）の集合とエッジ（辺）の集合により構成されるネットワー クの離散的構造のことを指しており、幾何学的には、変数をノード として与えた上、直接的な因果関係にある変数の対は、エッジを介 して隣接させることにより表現する。

グラフィカルモデリングにおいて、任意の変数の対が直接的な因 果関係を持つか否かは、変数が量的変数の場合、偏相関係数を用い て判断する。ここで「直接的な因果関係」とは、ある原因変数と結 果変数において、その他の変数の值を固定したままで、原因変数の 值を変化させることによって、結果変数の分布が変化するような関 係のことである。本研究では、このような関係が変数間に認められ るとき、両者は直接的な影響関係にあると解釈する。

いま、標本の大きさが $n$ で、 $x_{1}, x_{2}, \cdots, x_{v}$ の $v$ 個の変数からなる 多変量データについて、その相関行列 $R$ の逆行列 $R^{-1}$ の $i j$ 成分を $r^{i j}$ とすれば、偏相関行列 $P$ の $i j$ 成分 $r_{i j}$.rest、寸なわち、 $x_{i}$ と $x_{j}$ 以外の全 ての変数を与えたときの $x_{i}$ と $x_{j}$ の偏相関係数は、次の式で表される。

$$
r_{i j \text { rest }}=\frac{-r^{i j}}{\sqrt{r^{i i}} \cdot \sqrt{r^{i j}}}
$$

偏相関係数は、相関係数と同様、 -1 から 1 の間の実数值をとり、 変数間の直接的な因果関係が強いほど絶対值は 1 に近づき、符号の 正負はそのまま相関の正負と一致する。

グラフィカルモデリングでは、相関行列 $R$ により得られた偏相関 行列 $P$ に対して、共分散選択と呼ばれる操作を加えることによって、 採用すべきモデルを探索する。共分散選択とは、いくつかの偏相関 係数を 0 とおいた相関構造モデルにより $R$ を近似し、さらに、近似 された相関行列に基づいて、偏相関行列を推定する方法である。ど の変数を 0 とおくは、データから判断することが必要となるが、本 研究では全ての変数間に直接的な因果関係が認められることを仮定 したフルモデルから出発し、偏相関係数を逐次 0 とおいていく減少 法を基本として、モデルの探索を行った。

このようにして得られるモデルは縮約モデルと呼ばれるが、縮約
モデル $R M$ がデータに適合しているかどうかは、逸脱度 $\operatorname{dev}(R M)$ を 用いて判断する。いま、フルモデルの下での相関行列を $R$ とし、 $R M$ の下での母相関行列 $\Pi$ の推定值を员と寸れば、 $\operatorname{dev}(R M)$ は次の式で 与えられる。ただし、 $\log$ は自然対数を、 $|A|$ は行列 $A$ の行列式を表 している。

$$
\operatorname{dev}(R M)=n \log \frac{|\hat{\Pi}|}{|R|}
$$

逸脱度 $\operatorname{dev}(R M)$ の值は、縮約モデル $R M$ がデータによく適合して いるときに小さくなる。また、 $R M$ が正しいという仮定の下では、 $\operatorname{dev}(R M)$ はカイ二乗分布に近似的に従うことが知られている。この とき、自由度 $d f$ は、共分散選択の過程で 0 とおいた偏相関係数の個 数である。以上の議論により、RMの適合性に関する有意確率 $p$ が、 下記の式により算出できる。ここに、 $\chi^{2}$ は $d f$ のカイ乗分布に従う 確率変数であり、 $\operatorname{Pr}(X)$ は確率変数 $X$ が正規分布に従うときの確率 を表す。

$$
p=\operatorname{Pr}\left(\chi^{2} \geq \operatorname{dev}(R M)\right)
$$

（2）式より明らかなように、標本の大きさ $n$ が大きいほど、逸脱 度 $\operatorname{dev}(R M)$ は大きくなるため、 $n$ にあまり影響を受けないモデルの 適合度指標として、下記の式で与えられる GFI が提案されている。 ここに、 $\operatorname{tr}(A)$ は行列 $A$ のトレースを表す。

$$
G F I=1-\frac{\operatorname{tr}\left[\left\{\hat{\Pi}^{-1}-(R-\hat{\Pi})^{2}\right\}\right]}{\operatorname{tr}\left[\left\{\hat{\Pi}^{-1} R\right\}^{2}\right]}
$$

GFI は 0 から 1 の間の実数值をとり、その值が大きいほど、モデ ルの適合度が高いことを示している。GFI は標本の大きさ $n$ による 影響が小さいが、一方で、自由度 $d f$ に敏感であり、 $d f$ が大きくなる ほど GFIは大きくなる。

$G F I$ に対して、自由度 $d f$ を無意味に大きく寸ることにペナルティ を課した適合度指標として、AGFI が提案されている。AGFIは、変 数の数を $v$ とおき、次の式で表される。ここで、GFIの值との差が 大きい場合、その縮約モデルが不適当であると判断する。

$$
A G F I=1-\frac{v(v+1)}{2 d f}(1-G F I)
$$

一方、次式で与えられる $S R M R$ は、残差の平均平方の平方根をと ることによって、 1 次元に縮小した残差行列の指標である。ただし、 $r_{i j}$ は相関行列 $R$ の $i j$ 成分であり、 $\hat{\rho}_{i j}$ は推定された母相関行列 $\hat{\Pi} の$ $i j$ 成分である。

$$
S R M R=\sqrt{\frac{2}{v(v+1)} \sum_{i \leq j}\left(r_{i j}-\hat{\rho}_{i j}\right)^{2}}
$$

SRMR は、 0 から 1 の間の実数值をとり、その值が 0 に近いほど、 モデルの適合度は高い。

理論的根拠には乏しいものの、GFIについては、その值が 0.90 な いし 0.95 を超え、SRMRは 0.05 を下回るモデルが、経験的にあては まりが良いとされており ${ }^{13)}{ }^{14)}$ 、本研究でもこの值をモデル採用の基 準とした。また逸脱度の $p$ 值については、0.20を超えるモデルを採 用することとした。

以上のようにして得られたモデルについて、キャパシティに関す る観点からの考察を加える。 


\section{3. 住戸の建築特性の影響構造}

分析に用いた変数の相関行列、およびフルモデルの偏相関行列を 算出した結果を、表 2 に示す。ここでは、表の対角線の右上に相関 係数を、左下に偏相関係数を表している。相関行列に比して、偏相 関行列では絶対值の大きい成分が少なく、これは攵長な影響関係が 取り除かれた結果である。

フルモデルの偏相関行列を出発行列とし、共分散選択により得ら れた縮約モデルの偏相関行列の推定值を、表 3 に示す。ここで、表 の右上にはフルモデルの偏相関行列を表示した $\left.{ }^{(i)} 4\right)$ 。た、共分散選 択に際して值を 0 とおいた偏相関係数は、下線を引いて示してある。 なお、縮約モデルの算出法の制約により、一度に 0 とおける偏相関 係数の数は一つと定まっているため、最終的な縮約モデルに到達す るまでには、偏相関係数を 0 とおく都度、偏相関行列を反復的に計 算する必要がある。この過程で、 0 とおいたほとんど全ての変数は、 最終的な縮約モデルにおいて、厳密に 0 ではなくなっている。得ら れた縮約モデルの適合度指標は、それぞれ $G F I=0.940 、 A G F I=0.883$ 、 $S R M R=0.049$ であり、逸脱度の $p$ 值は 0.2980 である。

縮約モデルのグラフによる幾何学的表現を、図 1 に示す。ここで、 エッジを介して隣接している変数は、偏相関係数を 0 とおいた以外 の変数の対である。なお、建設年は他の多くの変数と直接的な因果 関係をもち、図が煩雑となるため、ここでは省略した。また、以降 の分析も、建設年を省略したグラフに基づいて行うこととする。図 中では、表 1 に示した変数の分類に従って、ノードの地の色を変え てある。また、スケルトンの特性のみによって值が定まる変数は枠 線を太く、それ以外の変数、寸なわち、インフィルの特性が值に影 響する変数については、枠線を細く表現した注 5 )。変数名に付記され た番号は、表 1 の変数番号と対応している。エッジに付された值は 偏相関係数の推定值であり、その絶対值に従って線種を変えている。

縮約モデルにおいて、各変数はエッジを介して絡み合っており、 複雑な影響構造が認められる。ただし、グラフを注視すれば、そこ に大域的な構造を読み取ることができる。
いま、元となるグラフの部分グラフが極大に完全である注 6) とき、 これをクリークと呼び、クリークを構成するノードの数を、クリー クのサイズとする。ここで、図 1 に示したグラフからは、サイズ 4 以上のクリークが 4 つ抽出できる。

具体的には、スケルトン天井高・標準天井高・スラブ段差・スラ ブ下がり面積・設備機器一排水竪管最大距離からなるサイズ 5 のク リークを、まず挙げることができる。このクリークは、住戸の断面 計画と設備機器の配置が、密接な影響関係にあることを表している。

また、専有面積・私室面積・公室面積・水迴り面積からなるサイ ズ 4 のクリーク、専有面積・無空私室面積・無空公室面積・無空水 廻り面積からなるサイズ 4 のクリークを見いだすことができるが、 これらのクリークは、住戸における室の面積配分に関連している。

最後に、有効採光壁面長 - 無空私室面積・無空公室面積 - 無空水 迴り面積・水廻り一採光可能外周壁最短距離からなるサイズ 5 のク リークを挙げることができ、これは住戸の採光条件と、無空となる 室の面積配分の関係を表している。

いずれのクリークにおいても、住戸の断面計画に関する変数と平 面計画に関する変数が同時に含まれることはなく、また、両者を直 接結ぶエッジの数は 3 つと少ない。この結果は、住戸の断面計画と 平面計画は、ほぼ独立して計画されているという筆者ら ${ }^{9)}$ の指摘と 矛盾しない。このとき、両者を間接的に取り結んでいるのは、設備 計画に関寸る変数である。この結果も、建設技術的な観点から適当 であるといって良いだろう。

ここで、スケルトンに関する変数に着目すると、その数は 7 であ り、また、図 1 に示したグラフより、これらの変数をノードとした 極大な部分グラフ注7を得ることができる。この部分グラフは連結で ある注8)が、スケルトン天井高と排水堅管数を結ぶエッジを取り除く と非連結となり（1－辺連結）、かつ、当該のエッジに対応する偏相 関係数の推定值は -0.074 と、その絶対值が極めて小さい。つまり、 スケルトンに限っても、断面計画と平面計画が独立して計画される という結果があてはまる。

表 2 フルモデルの偏相関行列（左下）と標本相関行列（右上） \begin{tabular}{|c|c|c|}
\hline $0 \leqq|r|<0.2$ & $0.2 \leqq|r|<0.4$ & $0.4 \leqq$ \\
\hline
\end{tabular} \mid$<0.6$ $0.6 \leqq|r|$

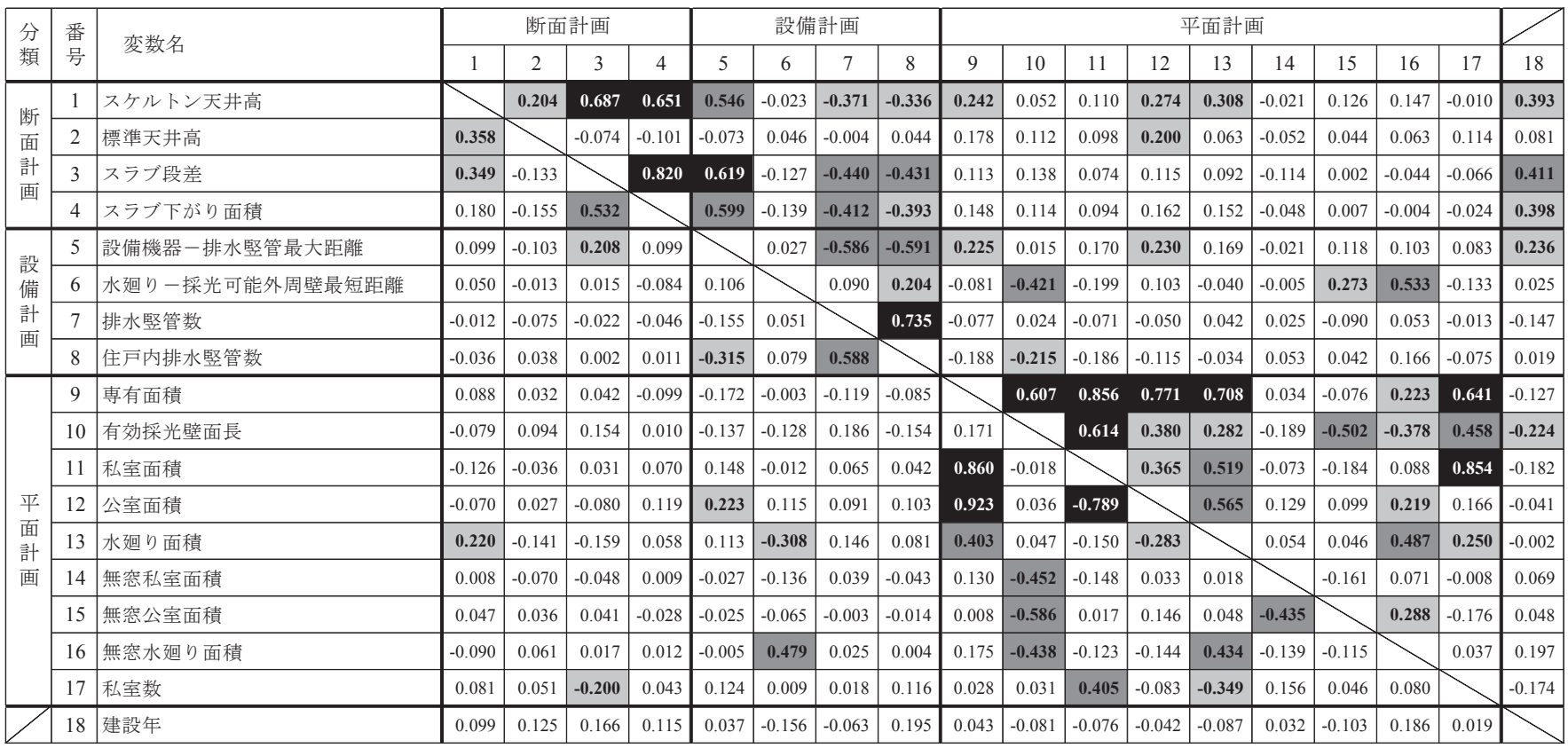


表 3 縮約モデルの偏相関行列（左下）とフルモデルの偏相関行列（右上）

\begin{tabular}{|c|c|c|c|c|c|c|c|c|c|c|c|c|c|c|c|c|c|c|c|c|}
\hline \multirow{2}{*}{ 分 } & \multirow{2}{*}{$\begin{array}{l}\text { 番 } \\
\text { 号 }\end{array}$} & \multirow{2}{*}{ 変数名 } & \multicolumn{4}{|c|}{ 断面計画 } & \multicolumn{4}{|c|}{ 設備計画 } & \multicolumn{9}{|c|}{ 平面計画 } & \multirow[b]{2}{*}{18} \\
\hline & & & 1 & 2 & 3 & 4 & 5 & 6 & 7 & 8 & 9 & 10 & 11 & 12 & 13 & 14 & 15 & 16 & 17 & \\
\hline \multirow{4}{*}{$\begin{array}{l}\text { 断 } \\
\text { 面 } \\
\text { 計 } \\
\text { 画 }\end{array}$} & 1 & スケルトン天井高 & 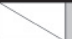 & 0.358 & 0.349 & 0.180 & 0.099 & 0.050 & -0.012 & -0.036 & 0.088 & -0.079 & -0.126 & -0.070 & 0.220 & 0.008 & 0.047 & -0.090 & 0.081 & 0.099 \\
\hline & 2 & 標準天井高 & 0.354 & 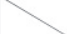 & -0.133 & -0.155 & -0.103 & -0.013 & -0.075 & 0.038 & 0.032 & 0.094 & -0.036 & 0.027 & -0.141 & -0.070 & 0.036 & 0.061 & 0.051 & 0.125 \\
\hline & 3 & スラプ段差 & 0.281 & -0.111 & & 0.532 & 0.208 & 0.015 & -0.022 & 0.002 & 0.042 & 0.154 & 0.031 & -0.080 & -0.159 & -0.048 & 0.041 & 0.017 & -0.200 & 0.166 \\
\hline & 4 & スラブ下がり面積 & 0.193 & -0.146 & 0.565 & 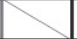 & 0.099 & -0.084 & -0.046 & 0.011 & -0.099 & 0.010 & 0.070 & 0.119 & 0.058 & 0.009 & -0.028 & 0.012 & 0.043 & 0.115 \\
\hline \multirow{3}{*}{$\begin{array}{c}\text { 設 } \\
\text { 備 } \\
\text { 計 } \\
\text { 画 }\end{array}$} & 5 & 設備機器－排水竪管最大距離 & 0.140 & -0.078 & 0.187 & 0.131 & 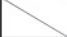 & 0.106 & -0.155 & -0.315 & -0.172 & -0.137 & 0.148 & 0.223 & 0.113 & -0.027 & -0.025 & -0.005 & 0.124 & 0.037 \\
\hline & 7 & 排水竪管数 & -0.074 & $\underline{0.000}$ & $\underline{-0.001}$ & $\underline{0.000}$ & -0.156 & $\underline{0.000}$ & 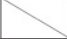 & 0.588 & -0.119 & 0.186 & 0.065 & 0.091 & 0.146 & 0.039 & -0.003 & 0.025 & 0.018 & -0.063 \\
\hline & 8 & 住戸内排水朢管数 & $\underline{0.000}$ & $\underline{0.000}$ & $\underline{0.000}$ & -0.001 & -0.297 & 0.121 & 0.620 & 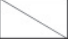 & -0.085 & -0.154 & 0.042 & 0.103 & 0.081 & -0.043 & -0.014 & 0.004 & 0.116 & 0.195 \\
\hline \multirow{8}{*}{$\begin{array}{l}\text { 平 } \\
\text { 面 } \\
\text { 計 } \\
\text { 画 }\end{array}$} & 9 & 専有面積 & $\underline{0.000}$ & 0.036 & $\underline{-0.001}$ & $\underline{-0.001}$ & $\underline{0.001}$ & $\underline{-0.001}$ & $\underline{0.000}$ & $\underline{-0.001}$ & & 0.171 & 0.860 & 0.923 & 0.403 & 0.130 & 0.008 & 0.175 & 0.028 & 0.043 \\
\hline & 10 & 有効採光壁面長 & $\underline{0.001}$ & $\underline{0.000}$ & $\underline{0.001}$ & $\underline{0.000}$ & $\underline{0.001}$ & -0.134 & 0.096 & -0.114 & 0.187 & 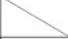 & -0.018 & 0.036 & 0.047 & $|-0.452|$ & -0.586 & -0.438 & 0.031 & -0.081 \\
\hline & 11 & 私室面積 & $\underline{0.001}$ & $\underline{0.000}$ & $\underline{0.001}$ & $\underline{0.000}$ & $\underline{0.000}$ & $\underline{-0.001}$ & $\underline{-0.001}$ & $\underline{0.000}$ & 0.863 & $\underline{-0.001}$ & & -0.789 & -0.150 & -0.148 & 0.017 & -0.123 & 0.405 & -0.076 \\
\hline & 12 & 公室面積 & $\underline{-0.001}$ & $\underline{0.000}$ & $\underline{0.000}$ & $\underline{-0.001}$ & $\underline{-0.001}$ & 0.111 & $\underline{0.000}$ & $\underline{0.000}$ & 0.925 & $\underline{0.000}$ & -0.815 & 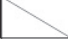 & -0.283 & 0.033 & 0.146 & -0.144 & -0.083 & -0.042 \\
\hline & 14 & 無空私室面積 & $\underline{-0.001}$ & $\underline{0.000}$ & $\underline{0.000}$ & $\underline{-0.001}$ & -0.001 & -0.133 & $\underline{0.001}$ & $\underline{0.001}$ & 0.145 & $\mid-0.453$ & -0.147 & $\underline{0.001}$ & $\underline{0.000}$ & & -0.435 & -0.139 & 0.156 & 0.032 \\
\hline & 15 & 無空公窒面積 & $\underline{0.001}$ & $\underline{0.000}$ & $\underline{0.001}$ & $\underline{0.000}$ & $\underline{0.000}$ & -0.058 & $\underline{0.000}$ & $\underline{-0.001}$ & 0.061 & $\mid-0.590$ & $\underline{0.000}$ & 0.092 & $\underline{0.001}$ & -0.434 & 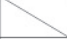 & -0.115 & 0.046 & -0.103 \\
\hline & 16 & 無空水迴り面積 & $\underline{-0.001}$ & $\underline{0.000}$ & $\underline{0.000}$ & $\underline{-0.001}$ & $\underline{0.000}$ & 0.481 & $\underline{0.000}$ & $\underline{0.000}$ & 0.152 & $\mid-0.426$ & -0.120 & -0.137 & 0.451 & -0.124 & -0.109 & $\lambda$ & 0.080 & 0.186 \\
\hline & 17 & 私室数 & $\underline{0.000}$ & $\underline{0.000}$ & -0.001 & $\underline{0.000}$ & $\underline{0.001}$ & $\underline{0.000}$ & $\underline{0.000}$ & $\underline{0.001}$ & -0.001 & $\underline{0.000}$ & 0.418 & $\underline{0.000}$ & -0.364 & 0.140 & $\underline{0.001}$ & 0.128 & & 0.019 \\
\hline & 18 & 建設年 & 0.145 & 0.095 & 0.126 & \begin{tabular}{|l|l|}
0.101 \\
\end{tabular} & $\underline{0.000}$ & -0.114 & -0.085 & 0.185 & $\underline{0.000}$ & -0.081 & $\begin{array}{ll}0.000 \\
\end{array}$ & -0.001 & -0.101 & $\begin{array}{ll}0.000 \\
\end{array}$ & -0.060 & 0.143 & -0.001 & \\
\hline
\end{tabular}

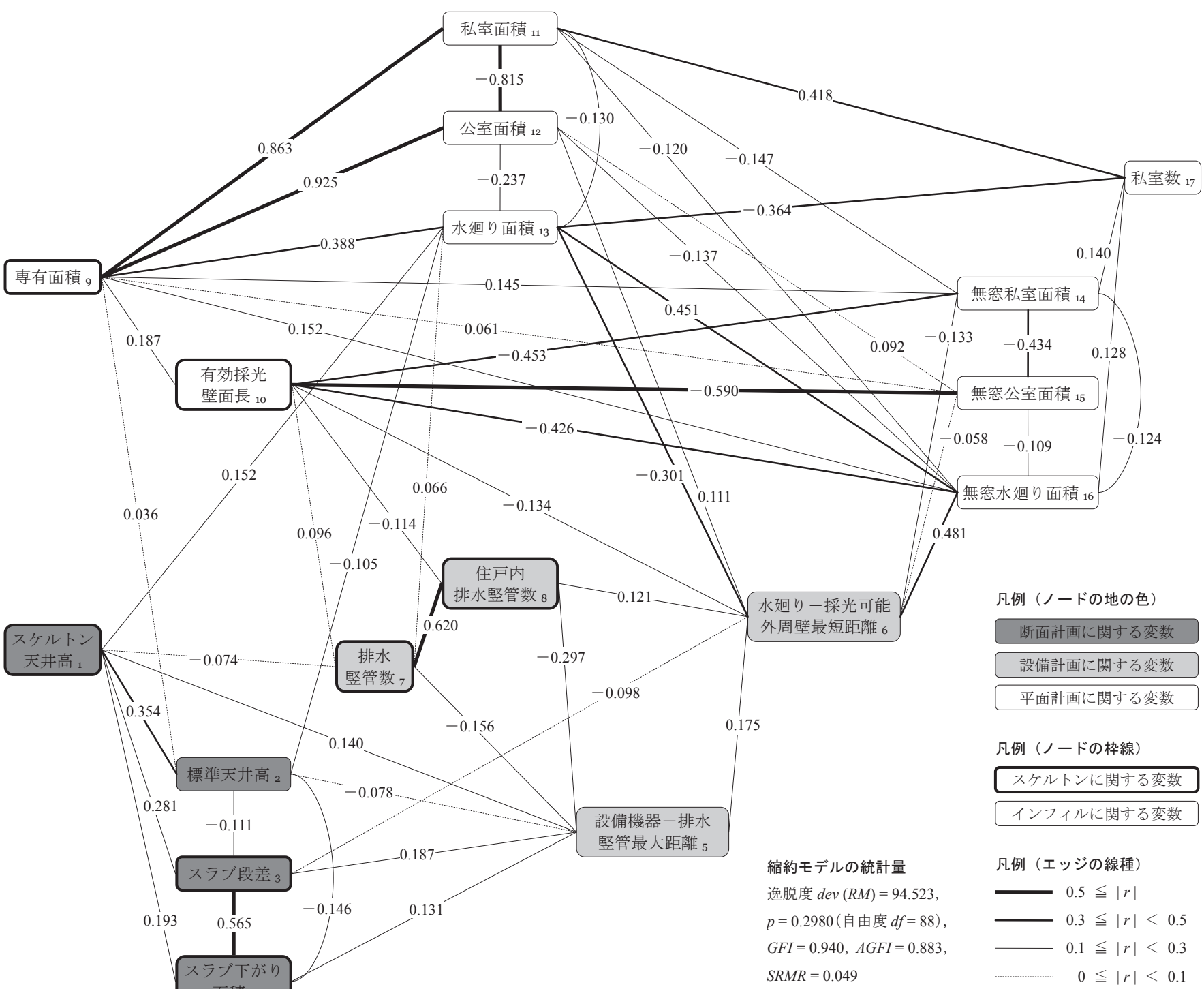

図 1 縮約モデルのグラフ表現 
また、スケルトンに関する変数をノードとする極大な部分グラフ と、インフィルに関する変数をノードとする極大な部分グラフを考 えると、両者を連結するエッジの集合は、スケルトンとインフィル のインターフェイスである。全ての変数のうち、スケルトンに関す る变数と直接の影響関係をもたない変数は、私室数のみである。以 上の結果は、スケルトンの特性が、インフィル計画に直接的な影響 を多大に及ぼしていることを示唆している。

いま、変数から変数へ至る経路を考え、そこに含まれるエッジの 数をその経路の長さと定義すれば、図 1 に示したグラフにおいて、 任意のスケルトンに関する変数から任意のインフィルに関する変数 に到達する最短経路の長さは、最長のものでもたかだか 3 である。 また、インフィルに関する変数はいずれも、偏相関係数の絶対值が 0.3 程度以上の、少なくとも 1 つのエッジと接続している。以上の ことより、スケルトンの計画が定まれば、インフィルに関する変数 の值は、ある程度予測可能であると考えられる。ただし、インフィ ルに関する変数をノードとする極大な部分グラフは連結であり、イ ンフィルの特性は、他のインフィルに関する特性からも直接的な影 響を受けている。

\section{4. キャパシティの評価手法}

\section{1. 定性的評価手法}

図 1 に示したグラフを用いて、当該のスケルトンがどのようなイ ンフィル計画に適したものであるか、判断することができる。例え ば、専有面積が大きいスケルトンでは、私室、公室、水廻りとも、 大きな面積を充てることが可能である。さらに、公室と水廻りの面 積をある程度抑えれば、私室数を増やすことができるが、一方で、 有効採光壁面長が十分でない場合は、無空の私室や無空の水迴りを 生じる可能性があることが、グラフから読み取れる。

逆に、変数を目的変数的に捉えて、計画の目安とすることも可能 である。例えば、水迴りに採光を確保したい場合、有効採光壁面長 を十分大きくすることが重要であるが、水廻りに近接して排水堅管 を計画することが併せて必要となる可能性もある。住戸内に排水竪 管を計画することを嫌うようであれば、排水堅管から離れた位置に 設備機器が計画できるように、スラブに段差を設けるなどの工夫が 必要であり、結果として、高いスケルトン天井高が必要となる。

このように、図 1 に示したグラフは、住戸計画における建築特性 の影響構造を示しているため、そこからキャパシティの質を定性的 に分析することが可能であるが、一方で、いずれの変数も他の複数 の変数から直接的な影響を受けているため、ある变数の值が変化し た際の、他の変数の值の変化を、このグラフを用いて予測すること は困難である。例えば、スケルトンの計画を策定する際に、そこで 成立可能なインフィル計画を、インフィルに関する変数の值域に基 づき定量的に予測したい場合などには、変数間の影響構造を参照し た上で、回帰モデルを新たに求めることなどが必要となる。

\section{2. 定量的評価手法}

回帰モデルの算出は様々な方法により可能であるが、以下では元 となる多変量データに、重回帰分析を適用する方法について述べる。

いま、任意の変数 $y^{i}$ に関する重回帰モデルを仮定し、これを推定 しようと寸れば、 $y^{i}$ を目的変数とした上、その変数と直接の影響関 係を持つ $w$ 個の変数 $x_{1}^{i} \sim x_{w}^{i}$ を縮約モデルから読み取り、それらを説
明変数とした重回帰分析を実行すればよい。ただし、重回帰モデル は説明変数が互いに独立であることを仮定しているため、偏相関係 数の大きい変数の対は、いずれかを説明変数から除外することが必 要である。以上により、未知の事例に関して、説明変数 $\left(x_{1}^{i}, \cdots, x_{w}^{i}\right)$ が特定の值 $\left(x_{10}^{i}, \cdots, x_{w 0}^{i}\right)$ をとったときの $y^{i}$ の期待值 $\hat{y}_{0}^{i}$ は、下記の 式により与えられる。ただし、解は推定された重回帰式の定数項、 $\hat{\beta}_{1}^{i} \sim \hat{\beta}_{w}^{i}$ は各変数の偏回帰係数である。

$$
\hat{y}_{0}^{i}=\hat{\beta}_{0}^{i}+\hat{\beta}_{1}^{i} x_{10}^{i}+\cdots+\hat{\beta}_{w}^{i} x_{w 0}^{i}
$$

前述のとおり、嵞は $y^{i}$ のる值の期待值であるから、これにより、 説明変数の值を変化させた場合の、目的変数の值の変化が予測でき る。実際には、 $y^{i}$ のとる值は正規分布に従うと仮定されているが、

（7）式は線形式であるため、算出された $\hat{y}_{0}^{i}$ を変数 $y^{i}$ に関するキャ パシティの比較尺度として用い、計画の目安とすることは可能であ る。つまり、 $y^{i}$ の值を大きくする、もしくは小さくするという要求 に対して、どのような計画が有利であるか、 $x_{1}^{i} \sim x_{w}^{i}$ の值を変化させ ることによって、定量的に比較分析することが可能である。

さらに、有意水準を $\alpha$ としたときの、変数 $y^{i}$ の期待值 $\hat{y}_{0}^{i}$ の予測区 間は、下記の式により求められる。ここに、 $s_{i}^{j k}$ は説明変数の分散共 分散行列 $S_{i}$ の逆行列 $S_{i}^{-1}$ の $j k$ 成分であり、 $V_{e}^{i}$ は重回帰式の誤差変動 の不偏分散である。また、 $t_{n-w-1}(\alpha)$ は自由度 $n-w-1$ をもつ $t$ 分布 における確率 $\alpha$ の゚゚ーセント点を表す。

$$
\hat{y}_{0}^{i} \pm t_{n-w-1}(\alpha) \sqrt{\left(1+\frac{1}{n}+\frac{1}{n-1} \sum_{j=1}^{n} \sum_{k=1}^{n}\left(x_{j 0}^{i}-\bar{x}_{j}^{i}\right)\left(x_{k 0}^{i}-\bar{x}_{k}^{i}\right) s_{i}^{j k}\right) V_{e}^{i}}
$$

予測区間は、未知の事例における変数 $y^{i}$ の值がどの範囲にあるか を予測するものなので、標本の大きさなどを考慮した上、 $\alpha$ を適切 に設定寸れば、算出された予測区間内で、 $y^{i}$ に関する計画が可能で あると考えることに、大きく無理はないだろう。すなわちこの範囲 が、 $y^{i}$ に関するキャパシティである。以下、この考え方を具体の変 数に適用してみよう。

仮に、スケルトンのみが与えられた上で、水迴りに採光が確保可 能か判断したいとする。このとき、水迴り一採光可能外周壁最短距 離の值が 0 となれば、浴室、洗面室、便所のいずれかの水廻りに採 光が得られるため、これを目的変数とした重回帰分析を実行する。

図 1 より、水迴り一採光可能外周壁最短距離と直接の影響関係を もつスケルトンに関する変数は、スラブ段差、住戸内排水堅管数、 有効採光壁面長であり、また、互いの偏相関係数も小さいため、以 上を説明変数とした重回帰分析を実行すると、その結果は表 4 に示 すようになる。

得られた重回帰式を用いて、標本における水廻り一採光可能外周 壁最短距離の予測值を算出した結果と、実測值の関係を、図 2 に示 す。重相関係数が 0.438 を示しているとおり、両者には相関が認め られ、得られた重回帰式は目安と寸る程度の予測には有効である。

図 2 には、キャップ付きの棒線を用いて、 $\alpha=0.1$ としたときの予 測区間もあわせて示している。ここで、下側予測区間が 0 を下回る 事例では、いずれかの水迴りへの採光を確保できる可能性がある。 つまり、スケルトンのみが与えられた状態では、多くの標本におい て、水迴りへの採光可能性があることが読み取れる。ただし、得ら れた重回帰式には説明変数とした変数以外の条件が組み込まれてい 
ないため、個別のスケルトンにおける計画可能域の判断には、あわ せて詳細な技術的検討が必要となる。一例を挙げれば、水迴りの設 置可能域を判断しようとする場合には、遮音性の問題から、スラブ 厚さの確認が必要となる。

同様の手続きは、インフィルの一部分を変更する、住戸の部分的 な改修を想定する場合などにも適用できる。いま、公室と水迴りが 隣接する平面を持つ住戸において、私室部分に手をつけず、かつ公 室と水廻りの面積配分を変えずに、水廻りの位置変更を伴う改修が 行われることを想定する。このとき、先の分析と同様、水廻りへの 採光が確保可能かどうか判断したいとすれば、水廻り一採光可能外 周壁最短距離を目的変数とし、スラブ段差、住戸内排水堅管数、有 効採光壁面長、公室面積、水廻り面積、無空私室面積を説明変数と した重回帰分析を実行すればよい。なお、設備機器一排水堅管最大 距離、無空公室面積、および無空水迴り面積も、目的变数と直接の 影響関係を持つが、これらは水迴りの位置が確定しないとその值が 定まらない変数であるため、説明変数からは除外する。

重回帰分析の結果を表 5 に、標本における目的変数の予測值と実 測值の関係、および $90 \%$ 予測区間を、図 3 に示す。重相関係数は 0.556 と、スケルトンに関する変数のみが与えられた場合の結果と比して 值が高く、また、予測区間は概して狭くなっている。つまり、水廻 りの位置は、スケルトンのみが与えられた場合と比して、より強く 制約を受けていると解釈できる。各標本の下側予測区間もよりばら ついており、このことは、水廻りの採光可能性に関するキャパシテ イについても、その差が大きくなっていることを示している。

先述のとおり、個別の住戸のキャパシティ分析に際しては、詳細 な技術的検討を行う必要があるが、以上に示したような手続きは、 計画段階におけるスケルトン設計の検討や、住戸の改修容易性の簡 易診断法の策定などに応用可能だろう。

\section{5. 結論}

本研究により得られた成果を、以下にまとめる。

1) 既存の集合住宅住戸を統計的に分析することによって、住戸の 建築特性が、当該住戸の他の建築特性に及ぼす影響を構造化し、 定量的に記述した。

2）建築特性の影響構造に基づき、住戸がどのような計画に適した ものであるか、定性的に分析する手法を示した。

3）住戸のスケルトンに関する条件を与えた上で、そこで成立可能 なインフィルの計画可能域を定量的に予測する手法を示した。 すなわち、住戸のスケルトンのキャパシティを評価する手法を 示した。

4) 上記のキャパシティの評価手法は、住戸のスケルトンに関する 一部の条件のみが与えられた場合の、他のスケルトンに関する 建築特性の計画可能域の予測や、インフィルの一部が変更され る場合の住戸計画の可能域の予測など、様々な場合にも適用で きることを明らかにした。

\section{付記}

本研究の一部は、文部科学省 科学研究費補助金 (研究代表者: 門 脇耕三，課題番号：17760496および 20760417）を受けて行ったもの である。
表 4 重回帰分析の結果（1）

\begin{tabular}{|c|c|c|c|c|}
\hline 目的変数 & 重相関係数 & 決定係数 & $\begin{array}{l}\text { 自由度調整済 } \\
\text { 決定係数 }\end{array}$ & 残差平方和 \\
\hline $\begin{array}{l}\text { 水廻り一外接壁面 } \\
\text { 最短距離 }\end{array}$ & 0.438 & 0.192 & 0.176 & 530.864 \\
\hline 説明変数 & 偏回帰係数 & 標準誤差 & t值 & $\begin{array}{l}\text { 標隻偏回帰 } \\
\text { 係数 }\end{array}$ \\
\hline スラブ段差 & 0.000 & 0.001 & -0.329 & -0.026 \\
\hline 住戸内排水竪管数 & 0.207 & 0.156 & 1.326 & 0.108 \\
\hline 有効採光壁面長 & -0.085 & 0.016 & -5.310 & -0.394 \\
\hline 定数項 & 3.520 & 0.487 & 7.226 & 2 \\
\hline
\end{tabular}

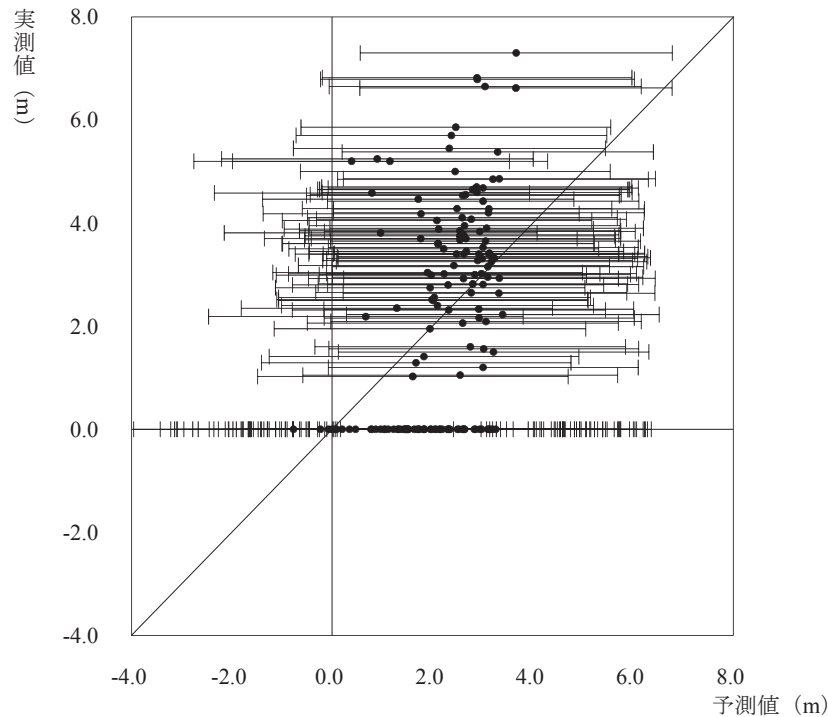

図 2 予測値と実測值の関係および $90 \%$ 予測区間（1）

表 5 重回帰分析の結果（2）

\begin{tabular}{|c|c|c|c|c|}
\hline 目的変数 & 重相関係数 & 決定係数 & $\begin{array}{l}\text { 自由度調整済 } \\
\text { 決定係数 } \\
\end{array}$ & 残差平方和 \\
\hline $\begin{array}{l}\text { 水廻り-外接壁面 } \\
\text { 最短距離 }\end{array}$ & 0.556 & 0.309 & 0.281 & 453.855 \\
\hline 説明変数 & 偏回帰係数 & 標準誤差 & t值 & $\begin{array}{l}\text { 標準偏回帰 } \\
\text { 係数 } \\
\end{array}$ \\
\hline スラブ段差 & -0.001 & 0.001 & -0.799 & -0.060 \\
\hline 住戸内排水竪管数 & 0.216 & 0.146 & 1.479 & 0.113 \\
\hline 有効採光壁面長 & -0.118 & 0.017 & -7.098 & -0.549 \\
\hline 公室面積 & 0.103 & 0.022 & 4.687 & 0.409 \\
\hline 水廻り面積 & -0.092 & 0.077 & -1.192 & -0.098 \\
\hline 無空私室面積 & -0.080 & 0.034 & -2.385 & -0.170 \\
\hline 定数項 & 2.382 & 0.680 & 3.503 & 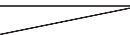 \\
\hline
\end{tabular}

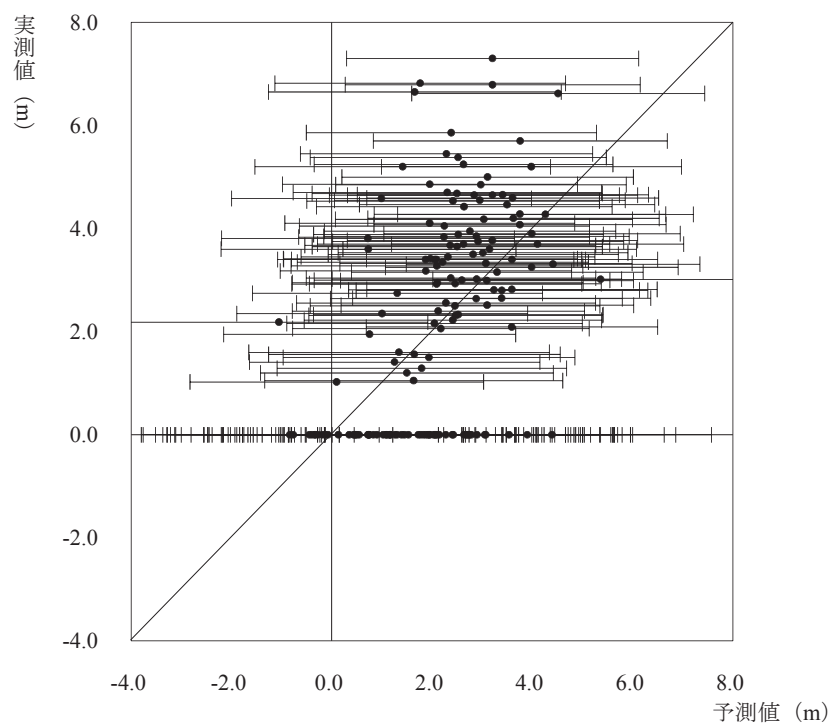

図 3 予測值と実測值の関係および $90 \%$ 予測区間（2） 
注1）建物高さの測定方法は、建築基準法施行令による。

注2）筆者ら（文献 9）で分析の対象とした標本には、建物高さが $45 \mathrm{~m}$ を超え る集合住宅が 2 事例含まれていたため、本研究ではこれを除外して分析 を行った。標本の構成に大きな違いはない。

注3) 本研究において、グラフィカルモデリングは、廣野によるアルゴリズム 「G-GM \& L-GM ver.2.1」を用いて行った。本アルゴリズムについては 文献 11 に詳しく、その理論的背景については、文献 12 に詳しい。また、 以降のグラフィカルモデリングに関する解説については、主に文献 11 ・ 文献 12 を参考とした。

注4) 表 3 中のフルモデルの偏相関行列は、表 2 中のそれとは行列の対角要素 を基準として対称な位置に表記したが、このことは、対角要素で対称な 行列は左三角を主と考え、右三角を省略する慣習があることに配慮した ためである。すなわち、表 2 ではフルモデルの偏相関行列を、表 3 では 縮約モデルの偏相関行列の推定值を主として扱っているためである。

注5) ここで、外周壁については、それが耐力壁か否かに関わらず、スケルト ンとして考える。

注6)「部分グラフ」とは、これを構成するノード集合とエッジ集合が、元と なるグラフのノード集合とエッジ集合の部分集合となるようなグラフ をいう。また、「完全グラフ」とは、これを構成する任意のノードの対 が、エッジを介して隣接しているグラフをいい、この状態を「グラフが 完全である」と表す。ここで「部分グラフが極大に完全である」とは、 部分グラフが完全グラフであり、かつそれを含む完全な部分グラフが、 自身以外に存在しない状態を指す。

注7)「極大な部分グラフ」とは、特定のノードで構成される部分グラフのう ち、エッジの数が最大のものをいう。

注8)「グラフが連結である」とは、グラフを構成する任意のノードから、そ れ以外の寸べてのノードまで、エッジを介して到達できる状態を指す。

\section{参考文献}

1) Bosma, K., van Hoogstraten, D. and Vos, M. : Housing for the Millions - John
Habraken and the SAR (1960-2000), NAi Publishers, 2001

2) Kendall, S. and Teicher, J : Residential Open Building, E \& FN Spon, 2000

3) 岡村幸一郎, 長谷英昭: 事務所建築における空間規模のフレキシビリテ イーの定義及び試算, 日本建築学会論文報告集, No.281, pp.121-128, 1979.7

4) 岡村幸一郎, 矢野資洋: 事務所建築のフレキシビリティーに関する研究, 日本建築学会論文報告集, No.297, pp.101-109, 1980.11

5)岡村幸一郎: 事務所建築における空間利用効率の組織遷移率による推定 理論および県庁舎におけるケース・スタディ, 日本建築学会論文報告集, No.331, pp.4-63, 1983.9

6) 安枝英俊, 高田光雄 : マス八ウジング期に建設された階段室型集合住宅 の躯体のキャパシティ分析 生活単位の個人化という視点からみた集 合住宅のキャパシティ分析手法の開発その 1, 日本建築学会計画系論 文集，No.569，pp.31-37，2003.7

7) Li, J. Q. : Designing Constraints for Capacity Analysis of Residential Floor Areas, A Thesis for the Master of Architecture, Department of Architecture, Ball State University, Jul. 2004

8）門脇耕三，深尾精一，鎌田一夫，小林秀樹，藤本秀一，宮本俊次：SI 住宅のスケルトンの改修キャパシティに関する研究 集合住宅の改修 性能の定量的評価手法に関する基礎的研究, 日本建築学会計画系論文集, No.543, pp.147-153, 2001.5

9) 門脇耕三, 深尾精一:集合住宅における住戸各部の計画内容の影響関係, 日本建築学会計画系論文集, No.588, pp.63-69, 2005.2

10) 門脇耕三，深尾精一 : 超高層住宅と中高層住宅における住戸の建築特性 の比較分析, 日本建築学会計画系論文集, No.601, pp.73-80, 2006.3

11) 廣野元久:グラフィカルモデリングのための G-GM \& L-GM データ解析 システム, 計算機統計学, Vol.15, No.1, pp.63-74, 2002

12) 日本品質管理学会 テクノメトリックス研究会 (編) : グラフィカルモデ リングの実際，日科技連出版社， 1999.5

13) 豊田秀樹：共分散構造分析 <入門編>, 朝倉書店, 1998.10

14) 狩野裕, 三浦麻子 : グラフィカル多変量解析, 現代数学社, 1997.10 